\title{
JPSE
}

(Journal of Physical Science and Engineering]

\section{Analisis Terjadinya Flare Berdasarkan Pergeseran Sudut Rotasi Group Sunspot pada Bulan Januari - Maret 2015 Melalui LAPAN Watukosek}

\begin{tabular}{l}
\hline Received \\
8 October 2016 \\
Revised \\
29 November 2016 \\
\\
Accepted for Publication \\
1 December 2016 \\
Published \\
16 December 2016 \\
\hline
\end{tabular}

\author{
M. F. R.Hasan ${ }^{1^{*}}$, Sutrisno ${ }^{1}$, B. Setiahadi ${ }^{2}$ \\ 1. Jurusan Fisika, FMIPA, Universitas Negeri Malang, Jalan Semarang No. 5, Malang, 65145, \\ Indonesia \\ 2. Lembaga Penerbangan dan Antariksa Nasional (LAPAN), Jalan Raya Watukosek No. 1 Gempol, \\ Pasuran, 67115, Indonesia \\ *E-mail: jendralrouf@gmail.com
}

\begin{abstract}
A research to determine the solar activity in the months from January to March 2015, and analyze the characteristics of flare on the rotation angle shifting of the sunspot group of sunspot sample observed, has been conducted. The method was observation and descriptive analysis of quantitative data. Determination of coordinates of sunspot was done using the software IDL. These observations were made in the Aerospace Observation Center (BPD) LAPAN Watukosek. Data were analyzed in the form of a sketch-owned BPD Sunspot LAPAN Watukosek, ie sunspot sketch of months from January to March in 2015 and the data was taken from NOAA. The results showed that the flare is not always the case in large class of sunspot groups, however, the small class was able to produce a flare. Most flares ware occur after experiencing a shift angle in the preceding or following although with angles that were not too large $\left(<10^{\circ}\right)$. The highest solar activity was occurred in January 2015 with the appearance of a sunspot group consisting of as many as 130 in 1063 sunspots.
\end{abstract}

Keywords: Sunspot, Flare, IDL (Interactive Data Language)

\begin{abstract}
Abstrak
Telah dilakukan penelitian yang bertujuan untuk mengetahui aktivitas Matahari pada bulan Januari-Maret 2015, serta menganalisis karakteristik terjadinya flare pada pergeseran sudut rotasi Group sunspot dari sunspot sampel yang teramati. Metode yang digunakan adalah observasi dan analisis data kuantitatif deskriptif. Penentuan koordinat sunspot dilakukan dengan memanfaatkan software IDL. Pengamatan ini dilakukan di Balai Pengamatan Dirgantara (BPD) LAPAN Watukosek. Data yang dianalisis berupa Sunspot sket milik BPD LAPAN Watukosek, yaitu sunspot sket bulan Januari-Maret pada Tahun 2015 dan data yang diambil dari NOAA. Hasil pengamatan menunjukkan bahwa flare tidak selalu terjadi pada group sunspot kelas besar, namun kelas kecil pun mampu menghasilkan flare. Sebagian besar flare terjadi setelah mengalami pergeseran sudut pada bagian preceeding atau following meskipun dengan besar sudut yang tidak terlalu besar $\left(<10^{\circ}\right)$. Adapun aktivitas Matahari paling tinggi terjadi pada bulan Januari 2015 dengan munculnya group sunspot sebanyak 130 yang terdiri dari 1063 sunspot.
\end{abstract}

Kata Kunci: Sunspot, flare, IDL (Interactive Data Language)

\section{Pendahuluan}

Bintang yang paling dekat dengan Bumi adalah Matahari dengan jarak rata-ratanya adalah 149.680.000 km. Matahari merupakan plasma dengan temperatur yang sangat tinggi. Matahari terdiri dari inti dan tiga lapisan kulit yaitu fotosfer, kromosfer, dan korona.

Aktivitas Matahari yang paling mudah diamati dari Bumi adalah sunspot (bintik Matahari) dan flare (ledakan Matahari). Bintik Matahari adalah suatu peristiwa pemunculan bintik-bintik hitam di permukaan Matahari.Kemunculan bintik Matahari dapat menunjukkan tingkat aktivitas 
Matahari.Yang berarti jika jumlah bintik dipermukaan Matahari banyak maka aktivitas Matahari pun tinggi. Sebaliknya jika jumlah bintik di permukaan Matahari sedikit maka aktivitas Matahari pun rendah [1].

Bintik Matahari terbentuk akibat perpotongan tabung medan magnet dengan fotosfer. Kemunculan bintik Matahari diawali dengan sebuah bintik hitam berukuran kecil. Semakin kompleks suatu konfigurasi bintik Matahari, semakin besar kemungkinan terjadi ketidakstabilan (instability) medan magnet, sehingga memicu peristiwa flare atau CME [2].

Selama kala hidupnya sunspot akan mengalami perubahan fisisnya antara lain perubahan luas dan medan magnet, baik kuat medan magnetnya maupun komplesitasnya [3]. Dengan mempelajari perubahan bentuk, jumlah dan pergerakan posisi titik berat spot-spot di bagian preceeding dan following yang terjadi selama evolusi group Sunspot maka dapat ditentukan karakteristik indikator fenomena Flare [4].

Flare merupakan suatu fenomena ledakan di Matahari sebagai akibat terbukanya salah satu kumparan medan magnet pada bagian Matahari [1]. Peristiwa flare terjadi karena akibat penumpukan medan magnet sunspot yang kehilangan daya untuk menahan desakan plasma yang terus masuk kedalamnya, bila penumpukan telah mencapai titik jenuhnya maka gangguan kecil saja sudah cukup untuk membebaskan sejumlah besar energinya. Medan magnet akan melepaskan plasma yang dikandungnya.

Flare pada Matahari dapat memengaruhi atmosfer Bumi. Kekuatan radiasi dari perjalanan flare menuju Bumi selama delapan menit dan bisa memengaruhi lapisan atmosfer Bumi paling atas menjadi lebih terionisasi dan meluas. Sinyal radio jarak jauh menjadi terganggu akibat perubahan lapisan ionosfer Bumi, dan dapat merusak komponen elektronik satelit [5].

Berdasarkan latar belakang yang telah dipaparkan yaitu beberapa aktifitas sunspot dapat memicu terjadinya flare, mulai dari perubahan luas sampai dengan pergeseran posisi sunspot. Pengamatan tentang pengaruh luasan sunspot terhadap potensi terjadinya flare sudah banyak dilakukan, maka dari itu dalam artikel ini memaparkan potensi terjadinya flare berdasarkan penyebab yang lain yaitu pergeseran sudut rotasi group sunspot, yang terjadinya pada bulan Januari hingga Maret 2015 dengan pengamatan di LAPAN Watukosek.

\section{Metode Penelitian}

Pengamatan dilakukan di Balai Pengamatan Dirgantara (BPD) LAPAN Watukosek, yang beralamatkan di Jalan Raya Watukosek, PO BOX 4 Gempol Pasuruan Jawa Timur. Tepatnya pada letak geografis $7^{\circ} 34^{\prime} 0^{\prime \prime}$ LU dan 11240'37" BT Pada Bulan Januari sampai dengan Maret 2015.

Penelitian ini menggunakan metode deskriptif yang menggambarkan hasil pengamatan, yaitu aktivitas Matahari berupa sunspot dan flare, dengan teleskop yang dimiliki oleh LAPAN yaitu teleskop sunspot dan bantuan data flare dari NOAA, yang kemudian data dari hasil pengamatan tersebut dipadukan dan akan dianalisis berdasarkan data yang telah dipilih.

Dengan variabel terikat adalah data flare yang diperoleh dari NOAA. Dan variabel bebas adalah group sunspot sampel, group sunspot sampel yaitu group sunspot pilihan yang telah memenuhi beberapa persyaratan yaitu sunspot yang berevolusi minimal selama lima hari dan berakhir dengan terjadinya flare, serta memiliki titik preceeding dan titik following. Data tersebut diperoleh dari sunspot sket LAPAN.

\subsection{Prosedur Kerja}

Prosedur kerja pada pengamatan ini melalui empat tahapan, yang pertama pengumpulan data, tahap kedua yakni melakukan seleksi data, kemudian melakukan pengolahan awal dan yang terakhir melakukan pengambilan data menggunakan software IDL.

2.2.1 Pengumpulan Data Hal pertama yang harus dilakukan dalam pengamatan ini yaitu mengumpulkan semua data, meliputi data sunspot sket dari LAPAN selama tiga bulan (Januari-Maret 2015) dan data sunspot dan flare dari NOAA (hal ini dilakukan karena pada saat itu teleskop H-alpha yang digunakan untuk mengamati flare yang dimiliki LAPAN dalam tahap perbaikan) pengambilan data dari NOAA bisa dilakukan secara online.

2.2.2 Seleksi Data Sebelum melakukan proses ini data yang diperoleh dari NOAA dicocokkan dengan data yang diperoleh LAPAN dengan memperhatikan saat terjadinya flare. Dari data yang diperoleh harus dilakukan seleksi, seleksi data dilakukan untuk memilih sunspot yang sesuai dengan 
kriteria. Adapun kriteria yang dimaksudkan adalah sunspot yang berevolusi minimal selama lima hari dan berakhir dengan terjadinya flare, serta memiliki titik preceeding dan titik following. Sunspot ini yang kemudian disebut dengan nama sunspot sampel.

2.2.3 Pengolahan Awal Pengolahan awal yang harus dilakukan adalah menscan data sunspot sket karena data yang nantinya akan diolah adalah dalam bentuk softfile. Proses berikutnya adalah melakukan konversi gambar hasil scan, karena tidak semua gambar bisa dibaca oleh software IDL, software IDL yang akan digunakan hanya bisa membaca gambar dalam bentuk JPEG dengan resolusi dan ukuran yang tidak terlalu besar yaitu $+-100 \mathrm{~KB}$. Proses ini dapat dilakukan dengan menggunakan software imagpal2.win. Tahap ini dilakukan di LAPAN Watukosek.

2.2.4 Pengambilan Data Pada proses pengambilan data hal pertama yang harus dilakukan adalah menginstal software IDL pada komputer. Setelah itu membuka aplikasi IDL kemudian memanggil input file berupa Sunspot sket dengan cara memasukkan kode termasuk Po dan Bo. Dari sinilah bisa ditenntukan posisi sunspot dengan cara melakukan klik kiri dan kanan pada koordinat lintang utara sebelah barat dan timur, lintang barat kemudian lintang timur (masing-masing tiga kali) dan yang terakhir klik kiri dan kanan pada sunspot sampel yang telah ditentukan dalam dua daerah yaitu bagian terluar dari titik timur dan barat masing masing satu kali. Klik kiri digunakan untuk merekam data dan klik kanan untuk melepas. Kemudian output file akan keluar dalam bentuk notepad. Data yang diperoleh kemudian dimasukkan dalam bentuk table, dengan bantuan Microsoft Excel. Perlu diingat bahwa output dari IDL dalam satuan derajat.

\subsection{Teknik Analisis Data}

Teknik analisis data dipaparkan dalam skema pada Gambar 1. Hal pertama yang harus dilakukan dalam analisis data adalah memasukkan data output dari IDL ke dalam Microsoft Exel dalam bentuk table. Konsep awal yang ditanamkan yaitu, menentukan sunspot sampel titik timur pada hari pertama pengamatan sebagai acuan untuk hari-hari berikutnya (untuk satu data/ nomor grup sunspot sampel yang diamati). Dalam hal ini acuan yang dimaksudkan adalah titik nol ketika sunspot hari berikutnya ditranslasikan pada hari pertama.

Sunspot pada hari kedua dan seterusnya harus ditranslasikan menuju titik yang telah disepakati pada hari pertama yaitu titik timur. Hari-hari berikutnya digeser menuju titik timur hari pertama, kemudian jumlah dari translasi tersebut dijumlahkan kepada titik barat agar titik barat ikut berpindah mengikuti titik awal. Dari titik barat hari pertama dan hasil translasi inilah bisa diugukur besar sudut rotasi sunspot.

\section{Hasil dan Pembahasan}

\subsection{Aktivitas Matahari Berdasarkan Jumlah Kemunculan Group Sunspot pada Bulan Januari-Maret 2015}

Kemunculan bintik Matahari dapat mengindikasikan tingkat aktivitas Matahari. Dengan kata lain, jika jumlah bintik dipermukaan Matahari banyak maka aktivitas Matahari pun tinggi. Sebaliknya jika jumlah bintik di permukaan Matahari sedikit maka aktivitas Matahari pun rendah [1]. Selain bintik Matahari ada juga fenomena lain yaitu flare atau bisa dikenal dengan lidah api atau semburan yang keluar dari permukaan Matahari, yang kemunculannya diawali dengan munculnya sunspot.

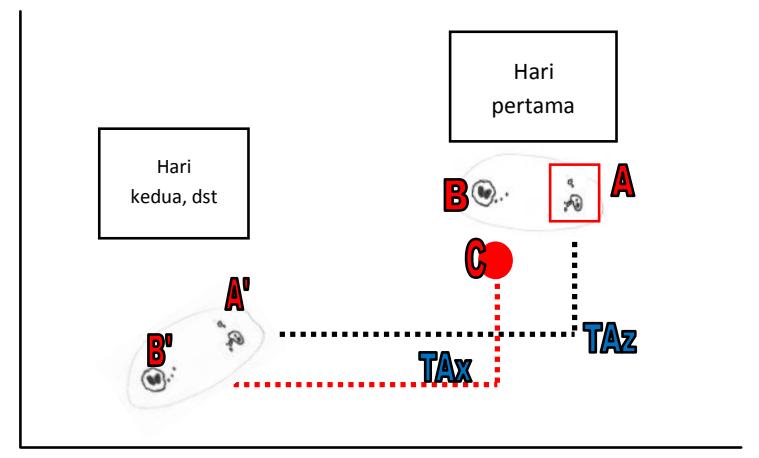

Gambar 1. Translasi sunspot sampel 


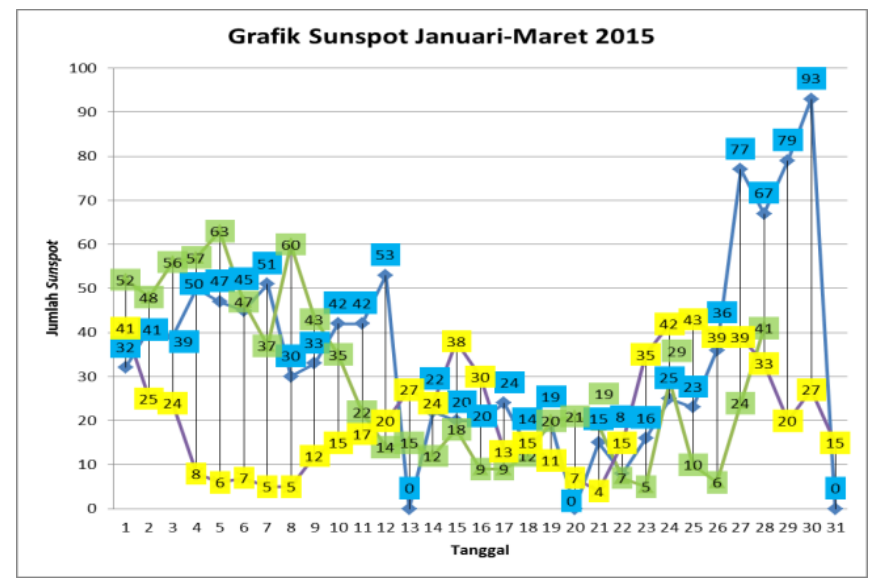

Gambar 2. Grafik hubungan antara jumlah Sunspot dan evolusi Sunspot dalam tanggal pada bulan Januari-Maret 2015

Pengamatan ini dilakukan mulai bulan Januari sampai dengan Maret 2015 di LAPAN Watukosek untuk memantau aktivitas harian Matahari. Grafik hasil pengamatan ditunjukkan Gambar 2. Bulan Januari ditandai dengan warna biru, sedangkan bulan Februari ditandai dengan warna hijau Muda dan untuk Bulan Maret ditandai dengan warna kuning dengan disertakan jumlah sunspot ditandai dengan warna yang sesuai dengan bulannya. Pada bulan Januari terdapat tiga sunspot yang bernilai nol yaitu pada tanggal 13, 20 dan 31, bukan berarti pada hari itu tidak ada sunspot sama sekali, melainkan pada hari itu LAPAN tidak melakukan pengamatan disebabkan kendala teknis.

Pada grafik tersebut jumlah sunspot tidak menentu, artinya dalam satu bulan tertentu jumlah sunspot selalu bertambah atau berkurang, bisa saja bertambah dan bisa juga berkurang, bisa juga tidak muncul sama sekali tergantung tingkat aktivitas Matahari. Begitu pula dengan evolusi sunspot, luas permukaan sunspot tidak selalu berkembang mulai kelas A-F, akan tetapi bisa jadi di tengah-tengah evolusi mengalami perkembangan yang naik turun bahkan bisa juga baru menginjak kelas $\mathrm{A} / \mathrm{B}$ kemudian hilang.

Pada Bulan Januari dan Februari Sunspot mula-mula bertambah banyak kemudian menurun kemudian naik lagi. Sementara pada bulan Maret jumlah sunspot mula-mula turun kemudian naik kemudian turun lagi dan naik lagi dan pada akhirnya turun lagi.

Jumlah total kemunculan sunspot yang teramati paling banyak terjadi pada bulan Januari dengan 130 grup sunspot dan terdiri dari 1063 sunspot (pengamatan dilakukan selama 28 hari pada bulan Januari), sedangkan pada Bulan Februari terdapat 83 grup sunspot dan terdiri dari 791 Sunspot, dan pada Bulan Maret terdapat 85 grup sunspot dan terdiri dari 662 sunspot. Jadi berdasarkan hasil pengamatan tersebut dapat dilihat selama tiga bulan tersebut aktifitas Matahari paling aktif terjadi pada bulan Januari.

3.2 Karakteristik Terjadinya Flare pada Pergeseran Sudut Rotasi Grup Sunspot dari Sunspot Sampel yang Teramati

Munculnya sunspot dapat digunakan sebagai pertanda bahwa aktifitas magnetik di daerah tersebut mulai meningkat dibandingkan dengan daerah lain yang tidak terdapat sunspot dipermukaan Matahari. Karena itu mekanisme pelepasan energi dalam suatu peristiwa flare selalu dikaitkan dengan evolusi grup sunspot. Kelas grup sunspot dan kompleksitas medan magnetiknya sangat menentukan produktivitas pembentukan flare [6].

Umumnya flare cenderung muncul pada grup-grup sunspot yang tergolong besar, karena pada grup sunspot yang tergolong besar dimungkinkan memiliki kompleksitas medan magnet yang besar pula. Oleh karena itu ketika terjadi penumpukan medan magnet sunspot dan sunspot tersebut tidak mampu menahan desakan plasma yang terus masuk ke dalamnya maka terjadilah flare. Jika penumpukan telah mencapai titik jenuhnya, maka gangguan kecil saja sudah cukup untuk membebaskan sejumlah besar energinya. Medan magnet akan melepaskan plasma yang dikandungnya.

Peristiwa medan magnet yang saling bersinggungan dapat diamati melalui gerak rotasi yang terjadi pada group sunspot antara titik preceeding dan following. Pada umumnya flare lebih sering terjadi pada grup-grup sunspot kelas besar (seperti kelas D, E, F, G, H, J). Namun berdasarkan data pengamatan grup sunspot Nomor 12290 dan 12293 (NOAA) atau 42 dan 47 (LAPAN) dimana grup 
tersebut tergolong sunspot dengan kelas kecil (untuk 42 kelas C dan untuk 47 kelas B), kemudian beberapa hari setelah mengalami evolusi ternyata mampu menghasilkan flare. Artinya sunspot kelas tersebut telah memasuki fase tidak sanggup lagi menahan desakan plasma yang terjadi, sehingga terjadilah flare, meskipun grup tersebut tergolong masih kecil. Hasil pengamatanya, diberikan pada Gambar 3.

Begitu juga dengan data pengamatan grup sunspot Nomor 12305 (NOAA) atau 54 (LAPAN) dimana grup sunspot tersebut tergolong kelas besar (Kelas E) namun tidak seketika itu pula mengalami flare, melainkan mengalami pergeseran ataupun aktivitas perpotongan medan magnet beberapa hari kemudian pada hari ke lima baru mengalami flare. Karena akibat pergerakan rotasi itulah terjadi peristiwa medan magnet yang saling bersinggungan yang mengakibatkan medan magnet terus mendesak sunspot dan ketika sunspot tidak mampu menahan maka terjadilah flare. Hasil pengamatanya, diberikan pada Gambar 4.

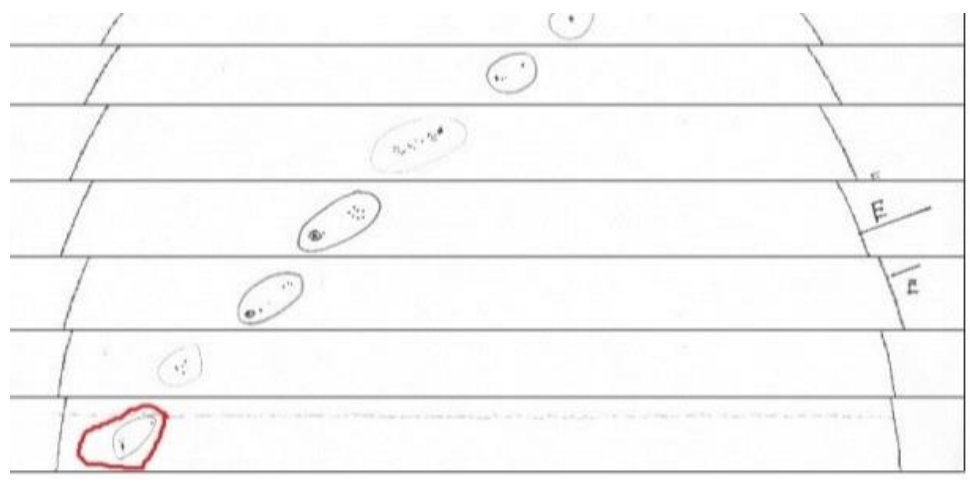

Gambar 3. Evolusi Sunspot Nomor 42

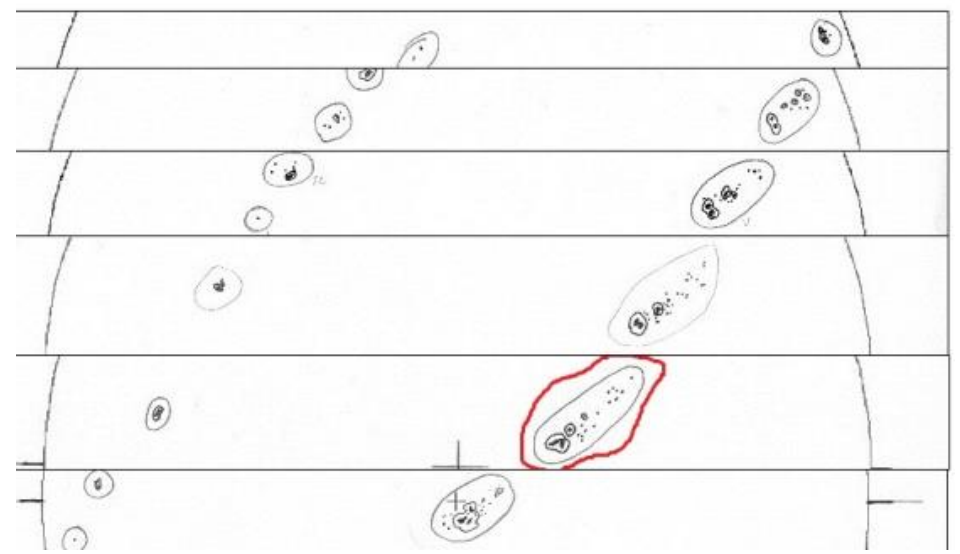

Gambar 4. Evolusi Sunspot Nomor 54

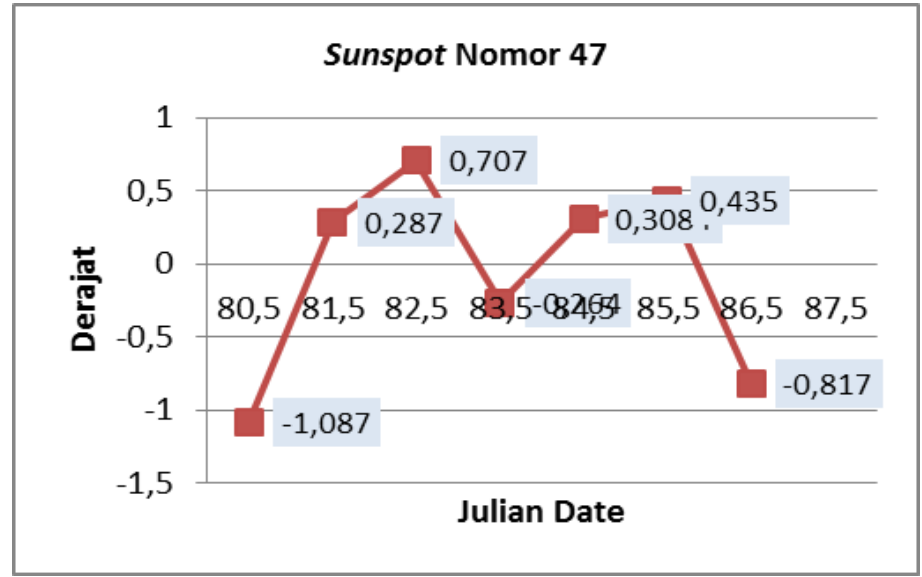

Gambar 5. Grafik hubungan besar Pergeseran Sudut Rotasi Sunspot dengan JD 
Dari beberapa perbandingan data di atas menunjukkan bahwa pergeseran sudut rotasi sunspot yang terjadi pada grup sunspot sampel bisa menjadi salah satu penyebab terjadinya flare. Tabel tersebut menunjukkaan bahwa flare terjadi setelah mengalami pergeseran rotasi sunspot pada sudut antara 1-10 derajat.

Besar pergeseran sudut rotasi tidak selalu naik atau pun sebaliknya, bisa juga naik kemudian turun, atau turun baru kemudian naik, dan bisa juga tetap tergantung besar medan magnet yang bekerja. Hasil pengamatan kami, diberikan pada Gambar 5.

Dari hasil pengamatan dilihat bahwa jarang sekali terjadi pergeseran posisi sunspot preceeding maupun following pada arah lintang baik utara maupun selatan yang terjadi secara signifikan $\left(>10^{\circ}\right)$. Adapun sebagian besar flare terjadi setelah mengalami pergeseran posisi bagian preceeding atau following meskipun dengan besar sudut yang tidak terlalu besar $\left(<10^{\circ}\right)$

\section{Kesimpulan}

Jumlah total kemunculan sunspot yang teramati paling banyak terjadi pada bulan Januari dengan 130 grup sunspot dan terdiri dari 1063 sunspot,pada bulan Februari terdapat 83 grup sunspot dan terdiri dari 791 sunspot, dan pada bulan Maret terdapat 85 group sunspot dan terdiri dari 662 sunspot. Jadi dapat disimpulkan bahwa selama tiga bulan tersebut aktifitas Matahari paling aktif terjadi pada bulan Januari.

Flare tidak selalu terjadi pada grup sunspot kelas besar, namun kelas kecil pun mampu menghasilkan flare, hal ini menunjukkan bahwa flare terjadi setelah mengalami pergeseran sudut pada bagian preceeding atau following meskipun dengan besar sudut yang tidak terlalu besar $\left(<10^{\circ}\right)$.

\section{References}

[1] J. Maspupu (2011), Prediksi Bintik Matahari Untuk Siklus 24 Secara Numerik. Jurnal. FMIPA UNY.

[2] G. S. Budhi, dkk (2011), Kombinasi Self-Organizing Map Neural Network dan K-Nearest Neighbor untuk Klasifikasi Otomatis Citra Kelompok Bintik Matahari, Konferensi Nasional Sistem dan Informatika, Universitas Kristen Petra Surabaya.

[3] Setiyowati (2012), Keterkaitan Luas Group Sunspot Kelas D, D, dan F Dengan Peristiwa Flare Kelas M dan X pada Siklus Matahari ke-23, Skripsi tidak diterbitkan : Universitas Pendidikan Indonesia.

[4] N. Widodo (2000), Menentukan perkiraan umur produktif Sunspot kelas D, E dan F berdasarkan frekuensi Flare, Warta LAPAN Vol. 2, No. 2.

[5] M. S. Munir (2005), Analisis Grup Sunspot dan Saat Terjadinya Flare, Skripsi. Tidak diterbitkan, Jurusan Fisika FMIPA Universitas Negeri Malang.

[6] Dani, Tiar, dkk (Tahun tidak disebutkan), Analisis Empirik Kejadian Flare Terkait dengan Perubahan Fisik Sunspot. LAPAN. 